\title{
Zastosowania naziemnego skanera laserowego (TLS) do oceny aktywności osuwisk, na przykładzie osuwiska Bodaki (Beskid Niski)
}

\author{
The use of Terrestrial Laser Scanner (TLS) to assess the activity of landslides, for example \\ of Bodaki landslide (Beskid Niski Mts.)
}

\author{
Jarosław Cebulski \\ Instytut Geografii i Przestrzennego Zagospodarowania, Polska Akademia Nauk, Kraków, cebulski@zg.pan.krakow.pl
}

Zarys treści: W artykule przedstawiono zastosowanie naziemnego skaningu laserowego (TLS) do oceny wielkości zmian zachodzących w obrębie osuwiska Bodaki (Beskid Niski). Analiza porównawcza czterech cyfrowych modeli wysokościowych uzyskanych w wyniku skanowania pozwoliła na określenie z bardzo dużą dokładnością ilości materiału który został usunięty z osuwiska przez potok Bartniankę. Zastosowana technika pozwoliła także na określenie obszarów w największym stopniu przekształconych oraz tempa przemieszczania się wybranych fragmentów osuwiska.

Słowa kluczowe: osuwiska, naziemny skaning laserowy, erozja koryt potoków, Beskid Niski

\begin{abstract}
This paper presents application of Terrestrial Laser Scanning (TLS) to assess the magnitude of the changes taking place within the Bodaki landslide (Beskid Niski Mts.). The comparative analysis of four digital elevation models obtained by scanning allowed to determine with high accuracy the amount of material that was removed from landslides by the Bartnianka stream. The technique also allowed to identification the most transformed areas and the movement rate of selected parts of the landslide.
\end{abstract}

Key words: landslides, Terrestrial Laser Scanning, stream channel erosion, Beskid Niski Mts.

\section{Wstęp}

Na terenie Karpat fliszowych, według dotychczasowych badań występuje około 95\% osuwisk dotąd zinwentaryzowanych w Polsce (Poprawa, Rączkowski 2003). Szacuje się, że ich liczba może wynosić ponad 50000 (Grabowski 2008). Rozwojowi osuwisk w Karpatach sprzyja urozmaicona budowa geologiczna, przede wszystkim duża zmienność litologiczna (Lach 1970, Jakubowski 1974).

W ostatnich 20 latach w obrębie Karpat odnotowano dużą aktywność ruchów masowych wywołanych ekstremalnymi opadami deszczu. W tym okresie powstało lub odnowiło się wiele osuwisk, doprowadzając do ogromnych strat gospodarczych (Poprawa, Rączkowski 1999, Forowicz 2010, Bajgier-Kowalska 2011): do zniszczenia wielu budynków mieszkalnych, gospodarczych, a także nfrastruktury komunikacyjnej i przesyłowej. Osuwiska uruchomione w wyniku katastrofalnych opadów wiosną 2010 roku doprowadziły do zniszczenia lub uszkodzenia ponad 1000 domów (Graniczny i in. 2012) oraz wielu kilometrów dróg i infrastruktury przesyłowej (linie wodociągowe, kanalizacyjne gazowe) (Cebulski 2012).

W celu minimalizacji szkód wywołanych tym destrukcyjnym procesem, prowadzone są prace inwentaryzacyjne w ramach projektu SOPO (System Osłony Przeciwosuwiskowej), mające na celu dokładne określenie rozmieszczenia tych form oraz ich cech morfolologicznych, morfometrycznych i morfodynamicznych (Grabowski 2008), a także rozpoznanie roli poszczególnych czynników wpływających na ich uaktywnienie.

Dużym wsparciem w badaniach osuwisk są dane uzyskane metodą skaningu laserowego (ang. LiDAR - Light 
Detection and Ranging). Dane te mogą być pozyskane za pomocą lotniczego skaningu laserowego (ang. ALS - Airborne Laser Scanning) lub naziemnego skaningu laserowego (ang. TLS - Terrestrial Laser Scanning). Krótki czas ich pozyskania oraz bardzo duża dokładność sprawiły, że metoda skaningu laserowego jest coraz częściej wykorzystywana w badaniach osuwisk (Wojciechowski i in. 2012, Wójcik i in. 2012, Graniczny i in. 2012).

Uzyskane tą metodą wyniki w postaci ,chmur punktów" (ang. point cloud) pozwalają obserwować nawet najmniejsze przemieszczenia w obrębie monitorowanej powierzchni (Sui i in. 2009, Dunning $i$ in. 2010, Grance $i$ in. 2014, Travelletti i in. 2014, Stumpf $i$ in. 2014). Odbywa się to przez analizę różnic w modelach terenu uzyskanych w różnych okresach. Przydatność tej techniki w monitorowaniu ruchów masowych dowiodły liczne badania, przede wszystkim określające strukturę stoków skalnych poddawanych odpadaniu i osuwaniu (Abellan 2006, Sturzenegger, Stad 2009, Kasperski i in. 2010) lub do określania wielkości osunięć ziemi (Teza i in. 2007, Prokop, Panholzer 2009, Travelletti, Malet 2012, Aryal i in. 2012).

Doświadczenia powyższe wskazują na zasadność użycia metody skaningu laserowego do badań osuwisk delapsywnych, uaktywniających się pod wpływem erozji bocznej potoków, powszechnie występujących w Karpatach Polskich. Bezpośredni kontakt jęzora osuwiskowego z nurtem cieku sprawia, że koluwia z osuwiska są stale wynoszone. Proces ten nasila się szczególnie w czasie wezbrań, gdy siła erozyjna potoków wzrasta, a materiał w obrębie osuwisk staje się bardziej plastyczny, podatny na erozję. Określenie z bardzo dużą dokładnością ilości materiału usuniętego z osuwiska może być przeprowadzone przy wykorzystaniu naziemnego skanera laserowego. Ponadto zastosowanie tej metody pozwala na określenie wielkości i przestrzennego rozkładu zmian w obrębie osuwiska, co jest istotne dla rozważań nad mechanizmem ruchów osuwiskowych i ich przyczyn.

Celem opracowania jest przedstawienie możliwości zastosowania TLS do oceny wielkości zmian w obrębie osuwiska oraz ich przestrzennego rozkładu, a także objętości materiału odprowadzonego z osuwiska przez potok.

\section{Położenie osuwiska Bodaki}

Badane osuwisko położone jest na wschodnim stoku Ostrej Góry (759 m n.p.m.), w miejscowości Bodaki, w Beskidzie Niskim (ryc. 1). Beskid Niski jest jednym z obszarów w polskich Karpatach w największym stopniu modelowanych przez ruchy masowe (Starkel 1972). Odsetek powierzchni osuwiskowych dochodzi tutaj do ponad 10\% powierzchni stoków (Wałach-Wrońska 2004).

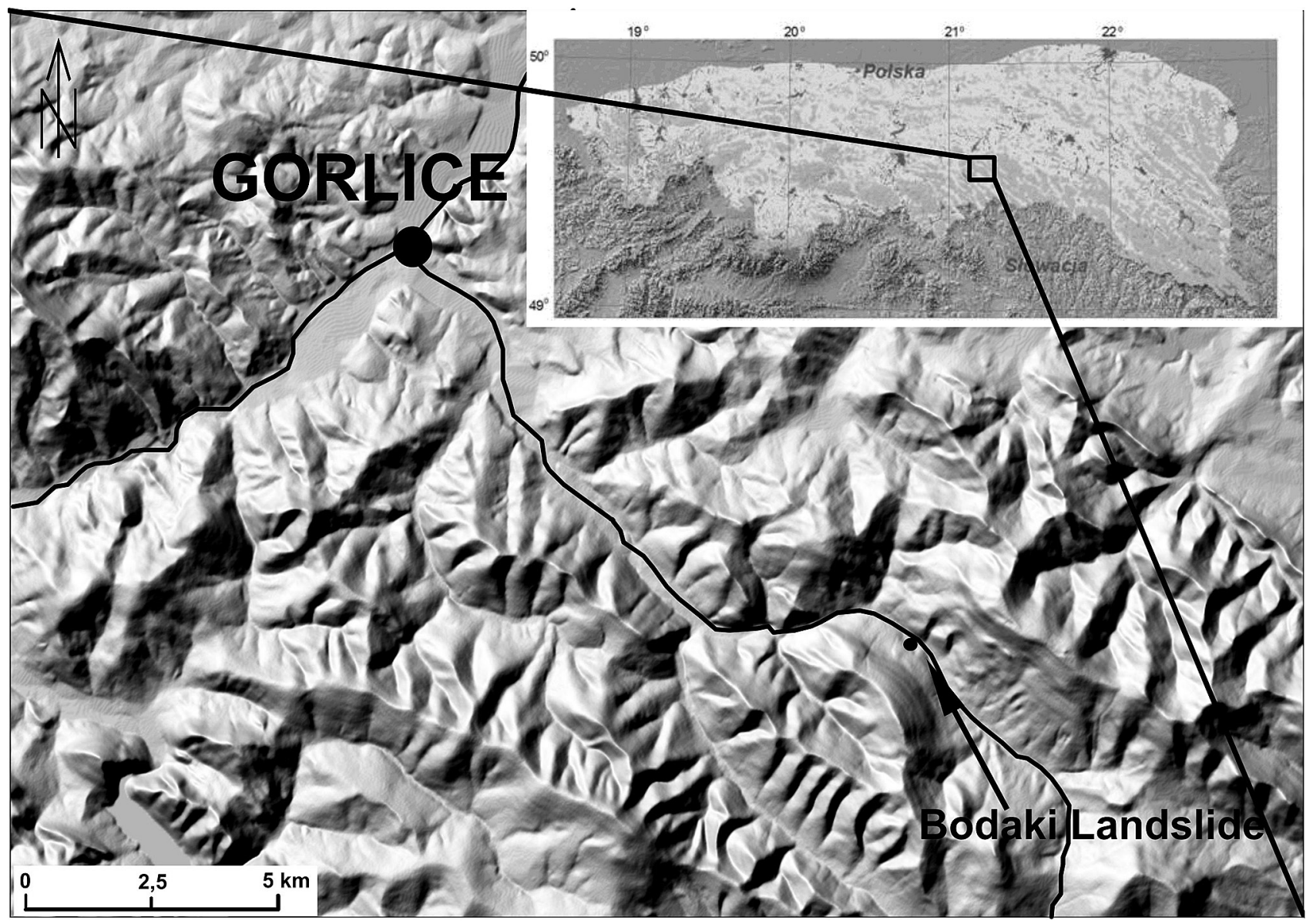

Ryc. 1. Lokalizacja osuwiska Bodaki

Fig. 1. Location of Bodaki landslide 


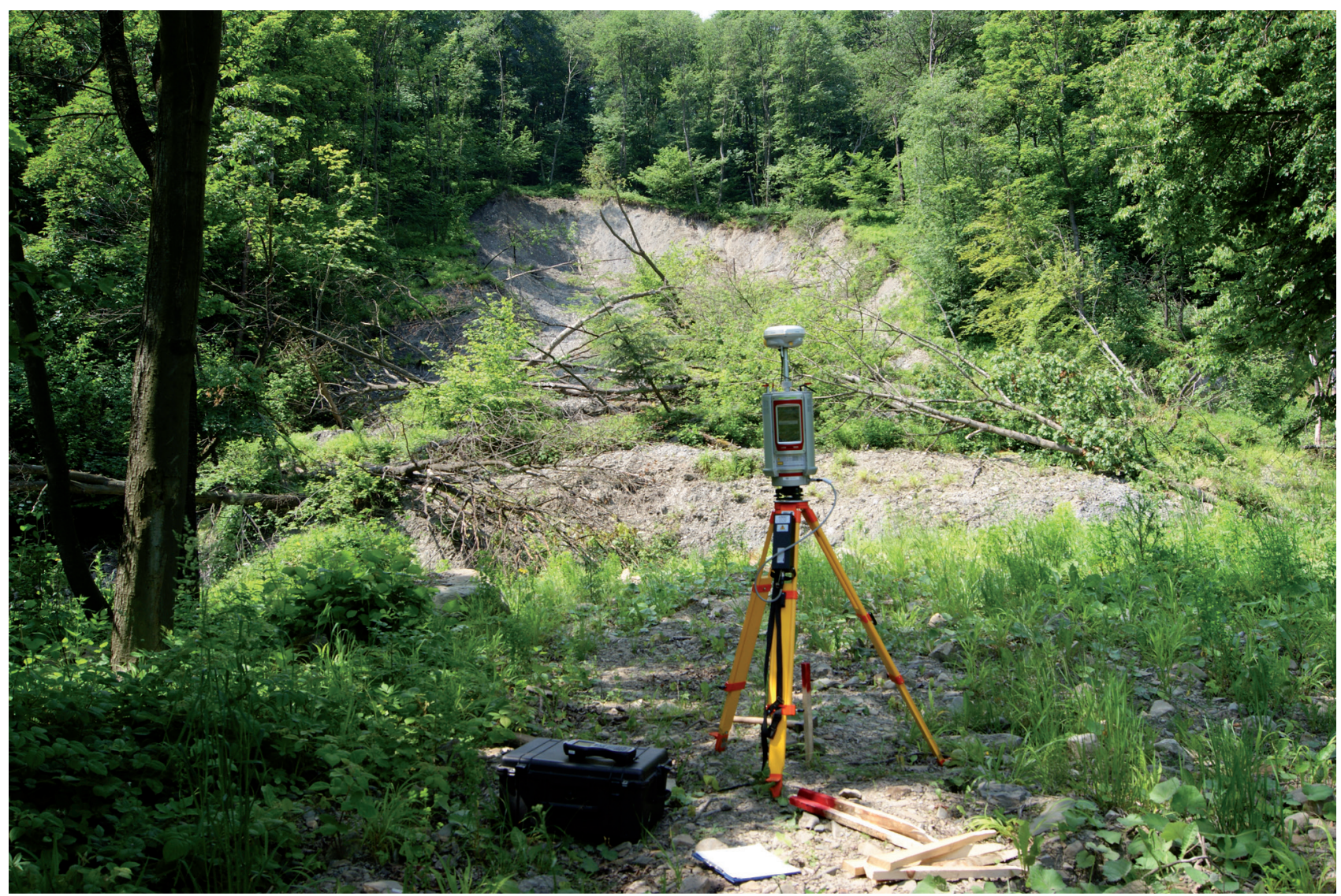

Ryc. 2. Skaner Riegl VZ 4000 na tle osuwiska Bodaki

Fig. 2. Scanner Riegl VZ 4000 on a background of Bodaki landslide

Osuwisko znajduje się w obrębie północnej części płaszczowiny magurskiej, zwanej strefą Siar. Obszar ten jest zbudowany z piaskowców z Wątkowej, warstw inoceramowych oraz lupków pstrych (Koszarski 1976, Kopciowski i in. 1997). Jest to osuwisko obsekwentne, powstałe w wyniku erozji bocznej potoku Bartnianka.

Pomiary powierzchni osuwiska z zastosowaniem TLS obejmowały jedynie jego część uaktywnioną jesienią 2013 roku, o powierzchni $3240 \mathrm{~m}^{2}$ (ryc. 2). Wskutek uaktywnienia osuwiska jego jęzor wkroczył do koryta potoku Bartnianka. Spowodowało to zatamowanie przepływu wody i doprowadziło do powstania niewielkiego jeziorka zaporowego. Uaktywniona część osuwiska ma długość 83 m, szerokość ok. 35 m, a jej średnie nachylenie wynosi $17^{\circ}$.

\section{Metodyka badań}

Działanie skanera laserowego polega na pomiarze odległości urządzenia od badanego obiektu. Realizowane jest to przez pomiar czasu, który upływa od momentu wysłania wiązki lasera do jego powrotu do urządzenia, po uprzednim odbiciu od powierzchni. Znana prędkość rozchodzenia się fali elektromagnetycznej oraz zmierzony czas, w którym wiązka dodarła do celu, pozwala na obliczenie odległości badanego obiektu od urządzenia. Skaner rejestruje także, pod jakim kątem wysyłana jest wiązka lasera. Uzyskane elementy (odległość oraz kąt odchylenia każdego impulsu) pozwala na wyznaczenie współrzędnych przestrzennych XYZ powstałych punktów (chmury punktów) w układzie lokalnym skanera (Wężyk 2006). Skaner Riegl VZ 4000, którym wykonywane były pomiary, generuje ok 220000 punktów/sekundę, a dzięki połączeniu z precyzyjnym GPS RTK (Trimble R4), każdy z mierzonych punktów ma określone dokładne współrzędne geograficzne (ryc. 2).

Do oceny czasowych i przestrzennych zmian w obrębie osuwiska wykorzystano, opisywaną w wielu pracach (Teza i in. 2007, Prokop, Panholzer 2009, Travelletti i in. 2014, Aryal i in. 2012), metodę analizy różnic modeli terenu powierzchni osuwiska. Wykonano 4 serie pomiarowe w 2014 roku (kwiecień, czerwiec, wrzesień, listopad). Modele terenu uzyskane z poszczególnych pomiarów nałożono na siebie po uprzednim odfiltrowaniu warstwy roślinności. Dodatkowo w celu obliczenia wektora przemieszczeń obszarów najbardziej aktywnych, zastosowano metodę porównania $\mathrm{w}$ czasie położenia wybranych charakterystycznych punktów (Oppikofer i in. 2009).

\section{Analiza modeli różnicowych}

Zastosowana metoda naziemnego skaningu laserowego (TLS) w obrębie osuwiska Bodaki obejmowała wykonanie czterech cyfrowych modeli wysokościowych (DEM). Każdorazowo, wykonane pomiary były wzajemnie dopa- 


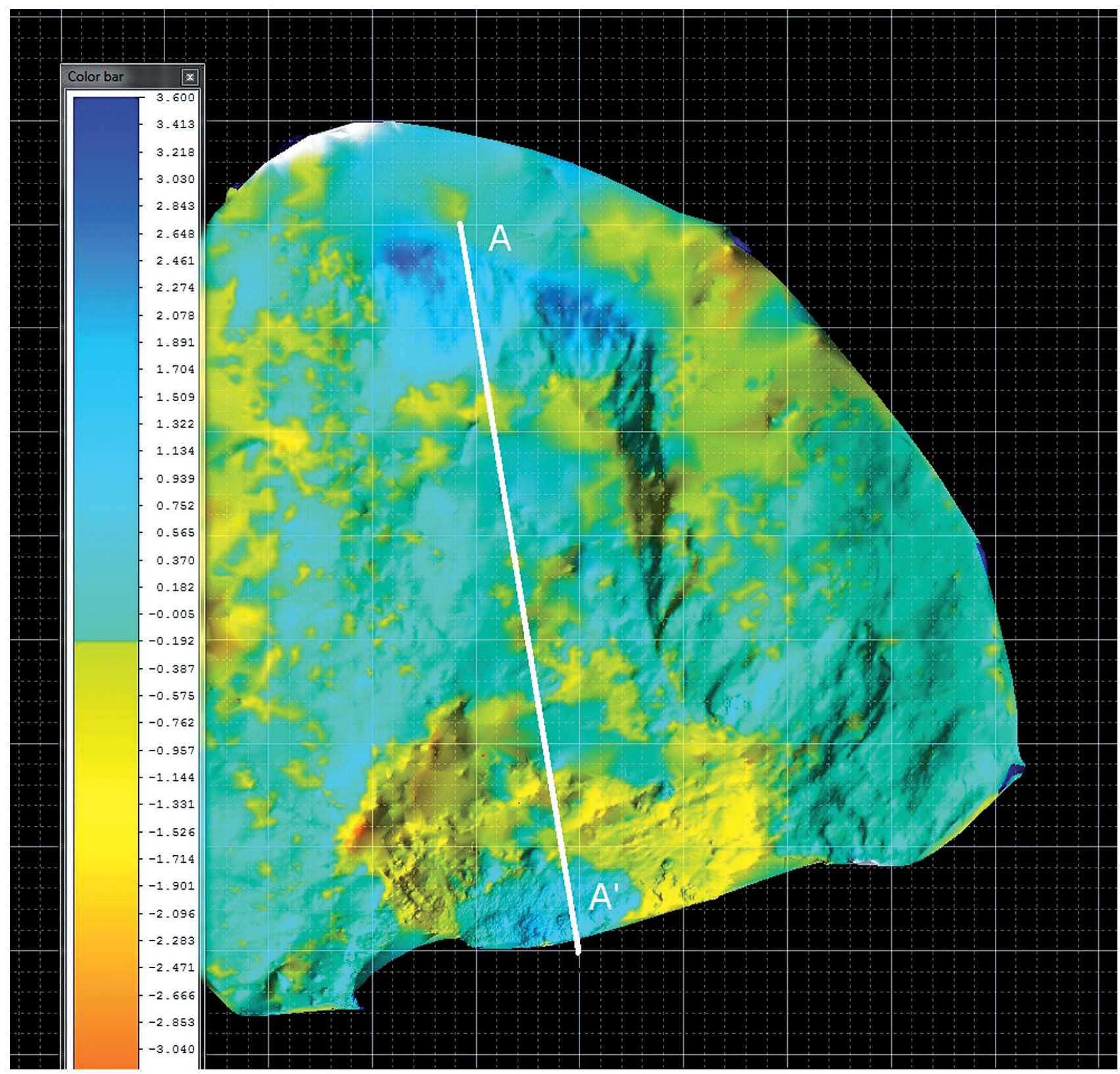

Ryc. 3. Różnice odległości pomiędzy cyfrowymi modelami wysokościowymi (kwiecień-listopad 2014)

A-A'- profil podłużny przez osuwisko (patrz ryc. 7)

Fig. 3. Distance differences between the digital elevation models (April-November 2014)

A-A' - longitudinal profile across a landslide (see fig. 7)

sowane przy pomocy narzędzia Multi Station Adjustment, umożliwiającego pracę bez konieczności umieszczania punktów referencyjnych na badanych obiektach. Po przeprowadzeniu procesu filtracji roślinności, chmury punktów przekształcano w numeryczne modele terenu (NMT).
Analiza różnic modeli terenu pozwoliła na ilościowe określenie zmian w obrębie osuwiska.

Nałożenie cyfrowych modeli wysokościowych z kwietnia i listopada (ryc. 3), w oprogramowaniu Riscan Pro, pozwoliło na ilościowe określenie różnic pomiędzy

Tabela 1. Zmiany w obrębie osuwiska Bodaki

Table 1. Changes in the landslide Bodaki

\begin{tabular}{|c|c|c|c|c|}
\hline \multirow{3}{*}{ Okres } & \multicolumn{2}{|c|}{ Zmiany objętości materiału } & \multirow{2}{*}{ - Różnica między okresami } & \multirow{2}{*}{ Bilans } \\
\hline & + & - & & \\
\hline & \multicolumn{4}{|c|}{$\left[\mathrm{m}^{3}\right]$} \\
\hline Kwiecień/czerwiec & 67,8 & 1972,2 & 2040,0 & $-1904,4$ \\
\hline Czerwiec/wrzesień & 19,5 & 115,8 & 135,8 & $-96,3$ \\
\hline Wrzesień/listopad & 31,2 & 53,4 & 84,6 & $-22,2$ \\
\hline Kwiecień/listopad & 73,1 & 2028,1 & 2101,3 & -1955 \\
\hline
\end{tabular}



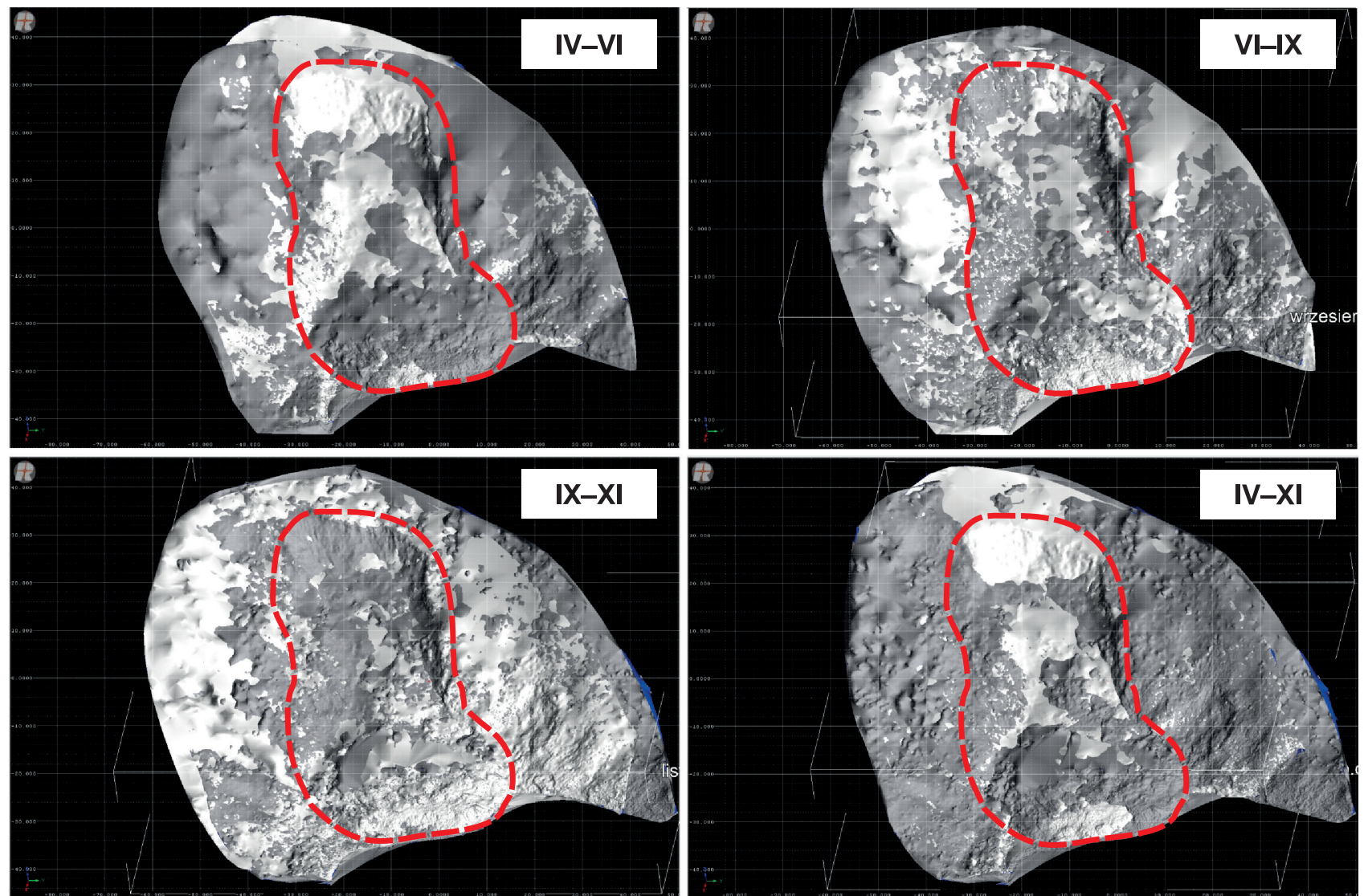

ubytek materiału

przyrost materiału

- zasięg badanej formy

Ryc. 4. Modele różnicowe osuwiska Bodaki

Fig. 4. Differential models of Bodaki landslide

tymi modelami. Wykonana w oprogramowaniu analiza porównawcza modeli terenu wykazała znaczący ubytek materiału w obrębie osuwiska wynoszący ponad $2028 \mathrm{~m}^{3}$ (tab. 1). Największa ilość materiału została usunięta ze skarpy głównej (ok. $1200 \mathrm{~m}^{3}$ ) i środkowej części czoła jęzora osuwiskowego (ok. $700 \mathrm{~m}^{3}$ ). Zarejestrowano także obszary, w których w tym okresie wystąpiła akumulacja materiału w stosunku do stanu z kwietnia. Przybyło ok. $73 \mathrm{~m}^{3}$, między innymi w obszarze jęzora osuwiskowego i poniżej skarpy głównej.

Analizy różnic cyfrowych modeli wysokościowych wykonane dla okresów: kwiecień-czerwiec; czerwiecwrzesień; wrzesień-listopad wykazały zróżnicowanie wielkości zmian w poszczególnych okresach (ryc. 4). Największe zmiany zaobserwowano w okresie kwiecień- czerwiec. Różnice między cyfrowymi modelami wysokościowymi wynosiły $2040 \mathrm{~m}^{3}$, z czego aż 1972 $\mathrm{m}^{3}$ stanowił materiał usunięty, a $68 \mathrm{~m}^{3}$ to materiał dodany. Zmiany objętości w okresie kwiecień-czerwiec stanowiły 97\% zmian zarejestrowanych w 2014 roku w obrębie badanej części osuwiska Bodaki. Przyczyną uaktywnienia osuwiska były prawdopodobnie rozlewne opady atmosferyczne w maju 2014 roku (ryc. 5), a także duża wilgotność gruntu po wiosennych roztopach. Zmiany powierzchni osuwiska w późniejszych okresach nie były już tak wielkie. Dotyczyły jedynie niewielkich fragmentów, szczególnie czoła jęzora osuwiskowego (ryc. 4), które było systematycznie erodowane przez potok Bartnianka.

\section{Analiza przemieszczeń wybranych punktów w obrębie osuwiska}

Połączenie skanera z precyzyjnym GPS RTK sprawia, iż uzyskane dane przestrzenne posiadają dokładne współrzędne, dzięki czemu możliwy jest monitoring przemieszczeń pionowych i poziomych, wybranych, charakterystycznych elementów (np. pień drzewa, głaz) w czasie między wykonami pomiarami (Sui i in. 2009, Dunning i in. 2010; Grance i in. 2014, Travelletti i in. 2014, Stumpf $\mathrm{i}$ in. 2014).

W celu określenia wielkości przemieszczeń wybrany został charakterystyczny punkt na osuwisku Bodaki (ryc. 6), który w czasie pomiaru kwietniowego znajdował się w odległości 18,6 m od pozycji skanera (tab. 2). W okresie prowadzenia pomiarów (kwiecień - listopad 2014) wybrany punkt został przesunięty o 5,9 m, z czego największe przemieszczenie odnotowano w okresie kwiecień -czerwiec (4,9 m) (tab. 2).

\section{Dokładność pomiaru}

Uzyskane w wyniku skanowania TLS cyfrowe modele wysokościowe obarczone są błędem wynikającym z do- 


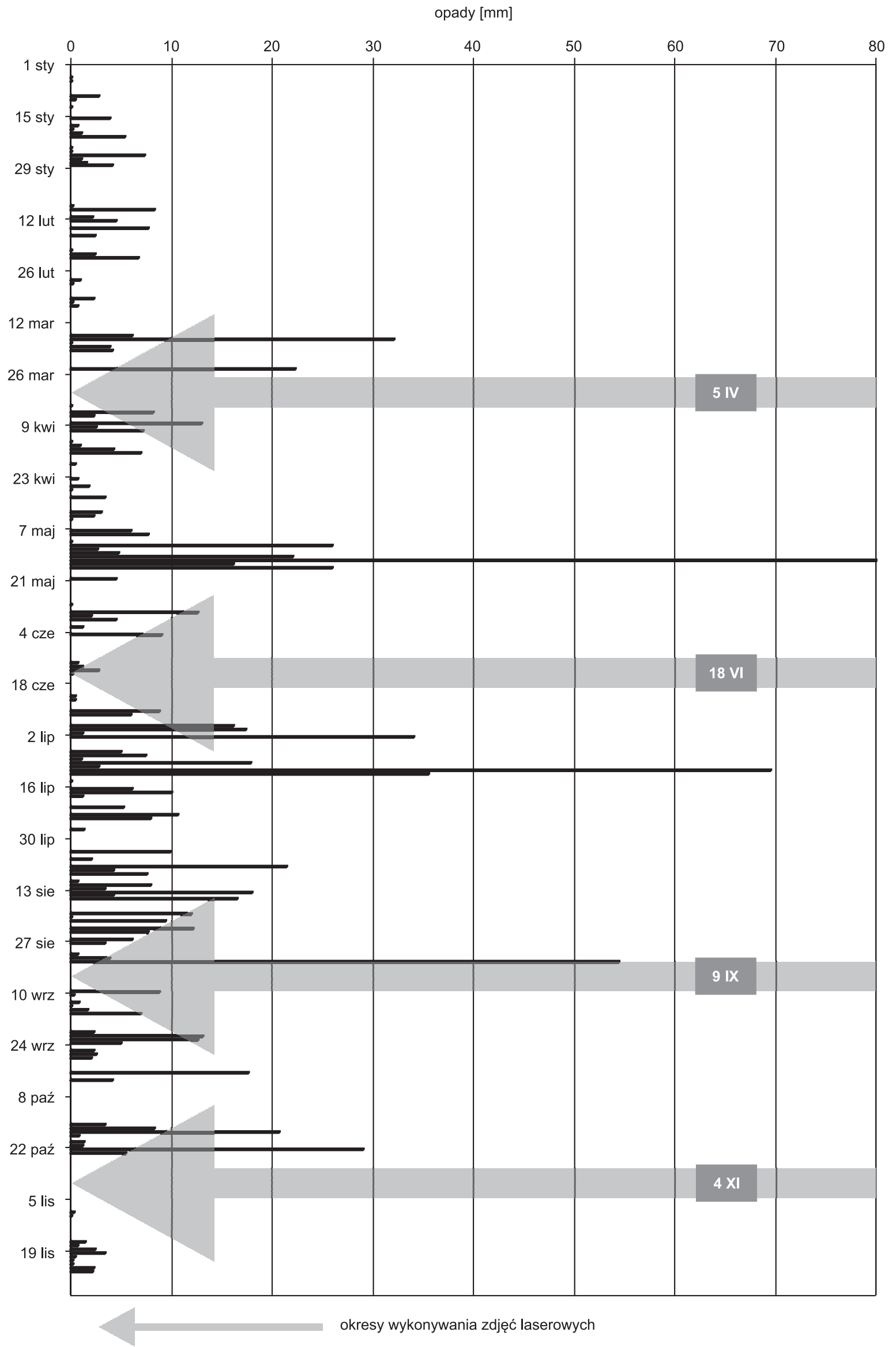

Ryc. 5. Opady atmosferyczne dla stacji Bartne w okresie 01.01-30.11.2014; strzałka wskazuje datę wykonania skanu Fig. 5. Precipitation for Bartne station in period 01.01-30.11.2014; arrow indicates the date of performing the scan 
Tabela 2. Wielkość przemieszczeń wybranego punktu w obrębie jęzora osuwiskowego

Table 2. The size of displacements of the selected point within the landslide tongue

\begin{tabular}{|c|c|c|c|c|}
\hline \multirow{2}{*}{ Okres } & \multirow{2}{*}{$\varphi$} & \multirow{2}{*}{$\lambda$} & Zmiana wysokości & Odległość od skanera \\
\hline & & & \multicolumn{2}{|c|}{$[\mathrm{m}]$} \\
\hline Kwiecień 2014 & N 4934'52.3416" & E $21^{\circ} 18^{\prime} 24.7428^{\prime \prime}$ & 0,0 & 18,6 \\
\hline Czerwiec 2014 & N 49³4’52.4208’" & E $21^{\circ} 18^{\prime} 25.1172^{\prime \prime}$ & $-2,7$ & 13,7 \\
\hline Wrzesień 2014 & N 49³4’52.4532” & E $21^{\circ} 18^{\prime} 25.1640^{\prime \prime}$ & $-3,33$ & 12,9 \\
\hline Listopad 2014 & N 493' $52.4522^{\prime \prime}$ & E $21^{\circ} 18^{\prime} 25.1635^{\prime \prime}$ & $-3,46$ & 12,7 \\
\hline
\end{tabular}
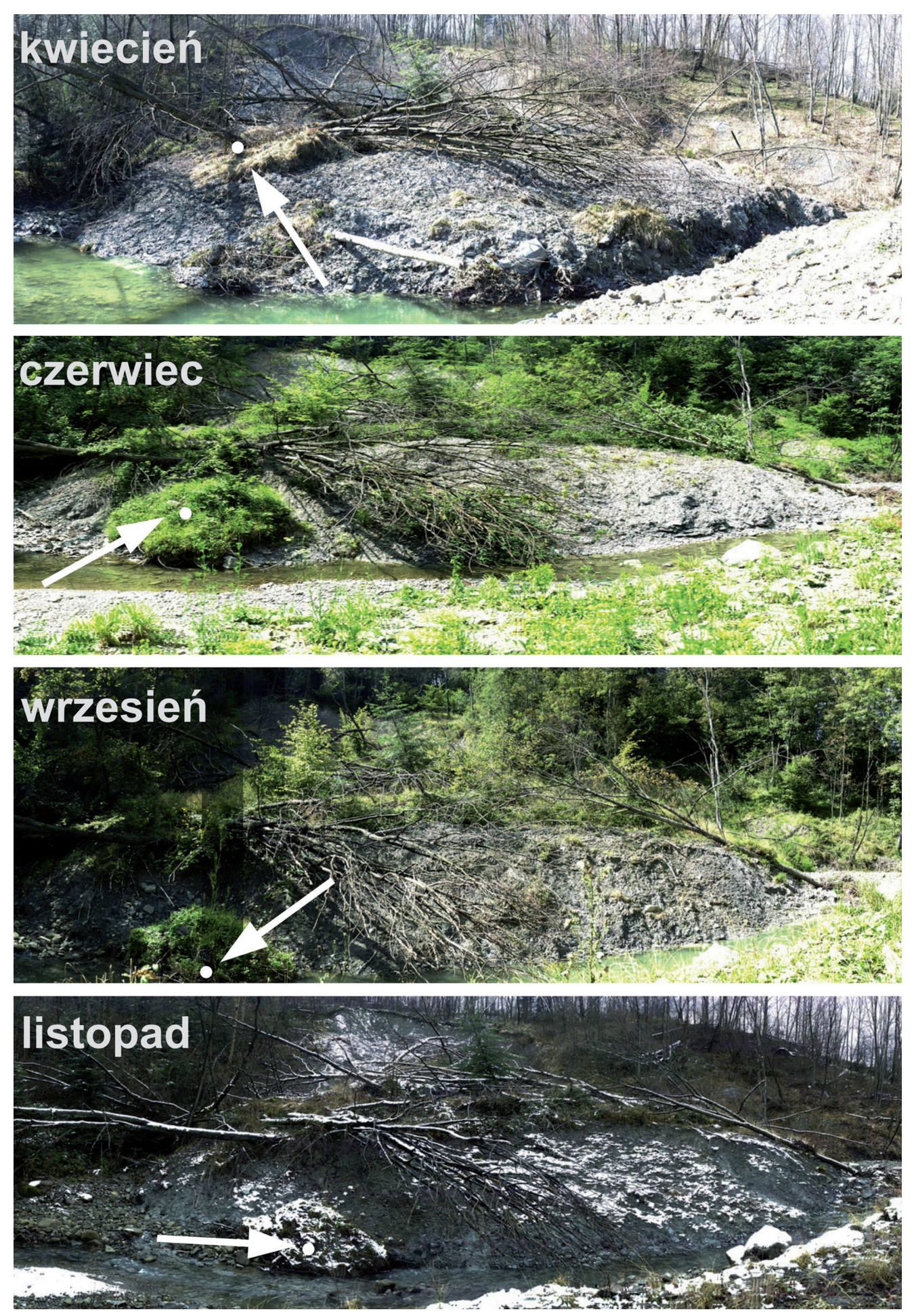

Ryc. 6. Zmiany w obrębie czoła osuwiska w okresie kwiecień - listopad 2014; Strzałka wskazuje ten sam punkt na osuwisku

Fig. 6. Front of the landslide in period April - November 2014; The arrow indicates the same point on the landslide 
kładności metody oraz stopnia odfiltrowania roślinności przy użyciu odpowiednich algorytmów. Nałożenie na siebie 4 modeli terenu fragmentów powierzchni stoku usytuowanego poza osuwiskiem, pozwoliło określić wielkość błędu. Różnica w modelach terenu na powierzchni $25 \mathrm{~m}^{2}$ wynosiła $0,71 \mathrm{~m}^{3}$, z czego przyrost materiału stanowił $0,6 \mathrm{~m}^{3}$, a ubytek $0,11 \mathrm{~m}^{3}$. Oznacza to, że średnia różnica odległości między nałożonymi na siebie modelami terenu wynosiła $3 \mathrm{~cm}$.

\section{Dyskusja}

Uzyskane wyniki badań, w postaci cyfrowych modeli wysokościowych, po nałożeniu na siebie pozwoliły na określenie fragmentów osuwiska w największym stopniu przekształconych, a także okresów, w których zachodziły największe zmiany. Metoda ta jest szczególnie przydatna, gdyż z bardzo dużą dokładnością możliwe jest określenie zmian w obrębie badanej powierzchni. Bezpośredni kontakt z potokiem czoła jęzora osuwiskowego, nieokrytego roślinnością sprawia, iż nawet $\mathrm{w}$ warunkach niewielkiego przepływu materiał z osuwiska jest systematycznie odprowadzany (ryc. 6). Proces ten nasila się szczególnie w czasie wezbrań, na co wskazuje korelacja przebiegu opadów (ryc. 5) i obrazu uzyskanego z pomiarów (tab. 2 , ryc. 6). Prowadzi to do zachwiania równowagi w obrębie osuwiska, a tym samym do uruchomienia materiału w jego obrębie.

Największe zmiany zaobserwowano w obrębie skarpy głównej, gdzie w okresie kwiecień - czerwiec ubyło ok. $1200 \mathrm{~m}^{3}$ materiału. Był on deponowany bezpośrednio poniżej skarpy głównej (ryc. 4), w centralnej części jęzora osuwiska, a także w jego niższych częściach. Równolegle zachodził proces erozji koluwiów przez Bartniankę, skutkujący wynoszeniem materiału dostarczanego z górnej części osuwiska (ryc. 7).

W późniejszych okresach (czerwiec - wrzesień; wrzesień - listopad) powierzchnia osuwiska została tylko nieznacznie przekształcona. Górna część osuwiska uległa stabilizacji, natomiast nieskonsolidowany materiał z frontowej części jęzora osuwiska był nadal erodowany przez Bartniankę (ryc. 6).

\section{Wnioski}

Pomiary aktywności osuwiska przy użyciu naziemnego skaner laserowego pozwoliły na:

1. Określenie $\mathrm{z}$ bardzo dużą dokładnością, objętości materiału wyniesionego z osuwiska przez potok oraz ziemności natężenia tego procesu.

2. Wyznaczenie obszarów w największym stopniu przekształconych oraz określenie wielkości i tempa przemieszczeń wybranych punktów w obrębie osuwiska.

3. Oszacowanie skali błędu zaprezentowanej metody oraz czynników odpowiedzialnych za jej wielkość. Wielkość błędu wynosząca $3 \mathrm{~cm}$ sprawia, że metodę TLS można uznać za najbardziej precyzyjną w badaniach zmian zachodzących w obrębie powierzchni terenu.

Uzyskane wyniki potwierdzają przydatność metody naziemnego skaningu laserowego (TLS) w badaniach osuwisk w Karpatach Polskich.

\section{Podziękowania}

Autor składa serdecznie podziękowania za cenne rady i konsultacje: dr hab. Zofii Rączkowskiej prof. PAN, a także dr Wojciechowi Rączkowskiemu za cenne uwagi i rady w trakcie przygotowywania artykułu. Dziękuje także anonimowym recenzentom za wartościowe uwagi, które wzbogaciły pracę i nadały jej ostateczny kształt. Praca naukowa finansowana ze środków statutowych IGiPZ PAN oraz z dotacji dla młodych naukowców i doktorantów IGiPZ PAN.

A

[m n.p.m.]

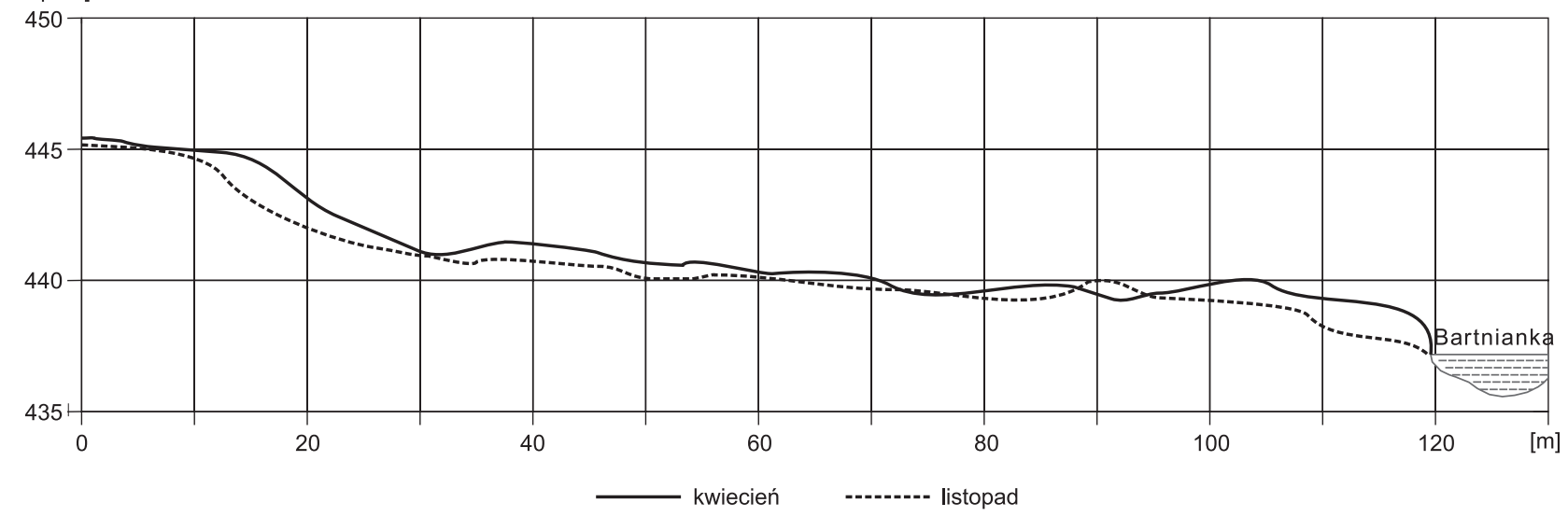

Ryc. 7. Zmiana profilu podłużnego osuwiska Bodaki w okresie kwiecień-listopad 2014 r. (patrz ryc. 3)

Fig. 7. Change in longitudinal profile of Bodaki landslides in the period April-November 2014. (see fig. 3) 


\section{Literatura}

Abellan A., 2006. Application of a long-range Terrestrial Laser Scanner to a detailed rockfall study at Vall de Núria (Eastern Pyrenees, Spain). Engineering Geology 88(3-4): 136-148.

Aryal A., Brooks B.A., Reid M.E., 2012. Landslide sub-surface characteristics inferred from Terrestrial Laser Scanning surface displacement fields. American Geophysical Union, Fall Meeting 2012. 1s.

Bajgier - Kowalska M., 2011. Procesy osuwiskowe w gminie Lanckorona na Pogórzu Wielickim jako efekt rozlewnych opadów w maju 2010 roku. Problemy zagospodarowania ziem górskich 58: 27-39.

Cebulski J., 2012. Ekonomiczne konsekwencje ruchów masowych w Szczepanowicach (Pogórze Rożnowskie) na przykładzie osuwiska Tubendza. Prace Studenckiego Koła Geografów Uniwersytetu Pedagogicznego w Krakowie 1: 17-25.

Dunning S., Rosser N., Massey C., 2010. The integration of terrestrial laser scanning and numerical modelling in landslide investigations. Quarterly Journal of Engineering Geology and Hydrogeology 43(2): 233-247.

Forowicz K., 2010. Osuwiska - żywioł którego nic nie zatrzyma. Środowisko 15-16: 423-424.

Grance J., Malet J.P., Dewez T., Travelletti J., 2014. Target Detection and Tracking of moving objects for characterizing landslide displacements from time-lapse terrestrial optical images. Engineering Geology 172: 26-40.

Grabowski D., 2008. System Osłony Przeciwosuwiskowej SOPO. Przegląd Geologiczny 56: 537-538.

Graniczny M., Kamiński M., Piątkowska A., Surała M., 2012. Wykorzystanie lotniczego skaningu laserowego do inwentaryzacji i monitoringu osuwiska w rejonie Łaśnicy (Gmina Lanckorona). Przegląd Geologiczny 60(2): 64-89.

Jakubowski K., 1974. Współczesne tendencje przekształceń form osuwiskowych w holoceńskim cyklu rozwojowym osuwisk na obszarze Karpat fliszowych. Prace Muzeum Ziemi 22: 169-193.

Kasperski J., Delacort C., Allemand P., Potherat P., Jaund M., Varrel E., 2010. Application of a terrestrial laser scanner (TLS) to the study of the Séchilienne Landslide (Isère, France) Remote Sensing 2(12): 2785-2802.

Kopciowski R., Zimnal Z., Jankowski L., 1997. Objaśnienia do Szczegółowej mapy geologicznej Polski w skali 1:50 000, ark. Osiek. Centralne Archiwum Geologiczne Państwowego Instytutu Geologicznego. Warszawa

Koszarski L., 1976. Rozwój najmłodszych osadów wschodniej części płaszczowiny magurskiej. Sprawozdania z posiedzeń Komisji Nauk PAN w Krakowie 20: 174-175.

Kopciowski R., Zimnal Z., Jankowski L., 1997. Szczegółowa mapa geologiczna Polski 1:50000, arkusz 1038 - Osiek. Narod. Arch. Geol., PIG-PIB, Warszawa.

Lach J. 1970. Fazy rozwoju form skalnych w Magurze Wątkowskiej. Rocznik Naukowo-Dydaktyczny WSP w Krakowie 40: 27-33.
Oppikofer T., Jaboyedoff M., Blikra L., Derron H., 2009. Characterization and monitoring of the Aknes rockslide using terrestrial laser scanning. Natural Hazards and Earth System Science 9: 10003-1019.

Poprawa D., Rączkowski W., 1999. Osuwiska i inne zjawiska geodynamiczne na obszarze środkowej części Karpat. [w:] Grela J., Słota H., Zieliński J. (eds.) Dorzecze Wisły - monografia powodzi - lipiec 1997. IMGW Warszawa. 23-42.

Poprawa D., Rączkowski W., 2003. Osuwiska Karpat. Przegląd Geologiczny 51(8): 685-692.

Prokop A., Panholzer H., 2009. Assessing the capability of terrestrial laser scanning for monitoring slow-moving landslides. Natural Hazards and Earth System Science 9: 1921-1928.

Starkel L., 1972. Charakterystyka rzeźby polskich Karpat i jej znaczenie dla gospodarki ludzkiej. Problemy Zagospodarowania Ziem górskich. 10: 75-150.

Stumpf A., Malet J.P., Allemand P., Ulrich P., 2014. Surface reconstruction and landslide displacement measurements with Pléiades satellite images. ISPRS Journal of Photogrammetry and Remote Sensing 95: $1-12$.

Sturzenegger M., Stad D., 2009. Quantifying discontinuity orientation and persistence on high mountain rock slopes and large landslides using terrestrial remote sensing techniques. Natural Hazards and Earth System Science 9: 267-287.

Sui L., Li J., Wang X., Zhao D., 2009. Monitoring landslides dynamics using multitemporal terrestrial laser scanning data. Second International Conference on Earth Observation for Global Changes. 1s.

Teza G., Galgaro A., Zaltron N., Genevois R., 2007. Terrestrial laser scanner to detect landslide displacement fields: a new approach. International Journal of Remote Sensing 28(16): 3425-3446.

Travelletti J., Malet J.P., 2012. Characterization of the 3D geometry of flow-like landslides: A methodology based on the integration of heterogeneous multi-source data. Engineering Geology 128: 30-48.

Travelletti J., Malet J.P., Delacourt C., 2014. Image-based correlation of Laser Scanning point cloud time series for landslide monitoring. International Journal of Applied Earth Observation and Geoinformation 32.

Wałach - Wrońska D., 2004. Wpływ procesów osuwiskowych na działalność człowieka oraz szatę roślinną Magurskiego Parku Narodowego. Folia Geographica, Series Geographica-Physica 35-36: 31-52.

Wężyk P., 2006. Wprowadzenie do technologii skaningu laserowego w leśnictwie. Roczniki Geomoatyki 4(4).

Wojciechowski T., Borkowski A., Perski Z., Wójcik A., 2012. Dane lotniczego skaningu laserowego w badaniu osuwisk - przykład osuwiska w Zbyszycach (Karpaty zewnętrzne). Przegląd Geologiczny 60(2): 95-102.

Wójcik A., 2010. Osuwiska w Małopolsce i ich katastrofalne skutki w 2010 r. [w:] Konferencja „Klęski żywiołowe - powódź i osuwiska w Małopolsce". Kraków.

Wójcik A., Wężyk P., Wojciechowski T., Perski Z., Maczuga S., 2012. Geologiczna i geomorfologiczna interpretacja danych z lotniczego skaningu laserowego (ALS) rejonu Kasprowego Wierchu (Tatry). Przegląd Geologiczny 61(4): 234-242. 